IN THE ReD Cross WORLd

\title{
SECOND MEETING OF HEADS OF INFORMATION AND PUBLIC RELATIONS
}

The Second Meeting of Heads of Information and Public Relations of National Red Cross, Red Crescent and Red Lion and Sun Societies opened on 9 June at the headquarters of the League of Red Cross Societies in Geneva. Representatives of 24 National Societies of Africa, Asia, Europe, North America and Latin America took part. Organized by the League in close co-operation with the ICRC, the meeting followed the first such conference organized in January 1967 by the ICRC.

The main items on the agenda were: information in the service of spreading the Red Cross idea; information in emergency situations and in the service of the permanent tasks of the Red Cross; co-operation in this field between the National Societies and the international Red Cross organizations; relations with mass media; information in developing countries; fund-raising and publicity; World Red Cross Day.

The vital role of information in gaining public support and understanding for the Red Cross was underlined by the three speakers who welcomed the delegates at the opening session. They were the President of the ICRC, Mr. Marcel A. Naville, the League Secretary General, Mr. Henrik Beer, and the Secretary General of the ICRC, Mr. Jean-Louis Le Fort.

Mr. Naville told the delegates that the meeting typified the communion of thought which permeates the whole Red Cross movement. He said it was a necessary complement to the work accomplished by the Red Cross in the field of human suffering, that the public be fully informed of this work. The ICRC, he said, had great need also to be informed of how the world viewed its action, critically as well as constructively.

Reviewing the great variety of Red Cross activities and the fact that information was an integral part of all Red Cross actions, 


\section{IN THE ReD Cross World}

Mr. Henrik Beer urged National Societies to keep abreast of all the latest developments in the field of communications in a world which is almost saturated with information. He pointed out that the meeting was taking place at a time when world events dramatically underlined the problems of Red Cross information: conflicts in South-East Asia and the Near East and terrible disasters in Europe and Latin America were competing for public attention, but all called for Red Cross aid. He also stressed the role of information in encouraging young people to participate in the work of the Red Cross.

Mr. Le Fort emphasized the importance of information as a factor for cohesion and solidarity and we give below some of the ideas he propounded:

... if I refer to the flexible and decentralised system of the Red Cross, it is in order to underline the importance of its counter-part: news dissemination, which is a characteristic attribute of any cybernetic type of organization. Without constant exchange of information and news between its various parts, the system would only be a juxtaposition of units deriving no benefit at all from each other's strength and exhausting themselves in solitude and anarchy.

Thus, news dissemination is a necessary factor of cohesion and solidarity; of force and vitality.

How is it achieved in the Red Cross?

The interchange of information is regulated about one or several reference criteria. At the beginning of the Red Cross, the creative idea, voluntary service to war caswalties, was a sufficiently clear and strong reference criterion to give direction to the nere mission. But as always happens, its activities became diversified as the member societies multiplied, so that the more complex organization made it necessary to educe and formulate what has become the backbone of the Red Cross, namely its principles and humanitarian law. How could the ICRC, on which this mission in incumbent, have carried it out had it not been informed of the practical conditions in which the Red Cross Societies work? And would the formulation of principles have served any purpose if National Societies had not learnt and assimilated them? This receipt and relay of news was one of the mainstays on which the Red Cross was built up.

Not only is information dissemination a cohesive factor; it is also the necessary stanchion of solidarity. The assistance which National Societies give each other so liberally and the support which they receive from the League in the discharge of its co-ordinating and developing mission, are well known. It is needless to underline the quantity of news 
and information which is the key to all that activity. And as information is conveyed better among people who know each other and who enjoy each other's confidence, it is not surprising that from the beginning of the Red Cross, its founders and prime movers have been always ready to travel.

$I$ shall dwell no longer on the vital role of news dissemination within the Red Cross. I shall now broach the other aspects of news dissemination, that is its function in relations between the Red Cross and the rest of the world. When consulting your working programme you will find that this is the aspect which will attract the major part of your attention.

The Red Cross must take root in the world or wither.

Do not hesitate to consider first the material aspects of this implantation. The needs which we try to meet are those of the underprivileged; of men whom conflicts have delivered into the hands of a hostile power and deprived of the usual safety, or men whom disasters and wars have thrown into physical, material or moral distress.

The services we provide for these unfortunates should necessarily be paid by others and it is both the essential objective and merit of news dissemination to maintain a spirit of altruism on the alert. In this same field of financial support there is another aspect of neres dissemination, namely to acquaint donors of the use made of their gifts in kind and in cash.

Having considered the material aspect let us now look at the human aspect, for although material resources are of course necessary to our mission, untiring dedication of many people is even more essential. How can we recruit them, how can we derive the greatest advantage from their professional or voluntary services if they are not made aware, by a constant stream of information, of the possibility which the Red Cross offers them of giving inestimable service for the benefit of the distressed?

To ensure the cohesion of Red Cross, to encourage manifestations of solidarity among its members, to promote support and vocations, these are so many fine and noble missions incumbent on you who are responsible for the dissemination of information. But there is yet a further mission which is extremely difficult, that is, to keep alive the understanding of the public for the Red Cross in conflicts.

It is of course obvious that in violent strife humanitarian decisions may come up against defence reflexes of part of the population and it is for National Red Cross Societies to infuence public opinion so that it understands and gives support to humanitarian measures.

At the working sessions of the meeting, which continued until 12 June, delegates were able to examine together methods for improving the transmission of information to the public, to empha- 


\section{IN THE Red Cross World}

size the need for faster and more modern techniques, and to seek new ideas for attracting youth to the work and ideas of the Red Cross. This Second Meeting of Heads of Information and Public Relations was indeed an opportunity for all participants to cast a wide glance around them in a particularly important field of Red Cross activities. We shall return to this topic when a full report has been published.

\section{AN EXHIBITION AT THE INTERNATIONAL RED CROSS MUSEUM}

We have several times mentioned the interesting International Red Cross Museum which was opened eleven years ago in one of the most beautiful manors of Castiglione delle Stiviere in North Italy. In that small palace an exhibition on "The Red Cross and the Franco-Prussian War of 1870-71" has just been opened.

The exhibition is the result of co-operation by the Henry-Dunant Institute, the ICRC, the League and several National Societies, assisted by the local authorities and the management of the museum. It was inaugurated on 16 June on the occasion of the visit to Solferino and Castiglione of the heads of information and public relations who attended the IInd meeting organized by the League in Geneva, and of which we give an account elsewhere in this issue.

It might be asked whether the Red Cross movement is justified in commemorating the centenary of historic events which concerned mainly only Germany and France. The answer is yes, for those events were a decisive stage in Red Cross development. It was during them that for the first time

a) the Geneva Convention, which had been ratified by both belligerents, was applied in practice;

b) the medical services of both armies were assisted by a National Aid Society for the Nursing of the Sick and the Wounded in the Field; 